\title{
Raptor declines in West Africa: comparisons between protected, buffer and cultivated areas
}

\author{
Jean-Marc Thiollay
}

\begin{abstract}
Since 1970 there has been a dramatic decline of large raptors and terrestrial birds in West African savannahs. Comparative dry season transect counts over 4,697 $\mathrm{km}$ of driven transects were performed in 2004-2005 in south-eastern Burkina Faso to assess the abundance of 41 raptor species and large terrestrial species in four National Parks and surrounding hunting zones and cultivated areas. Population sizes were estimated for larger taxa in protected areas using distance sampling and nest searching. Most large vultures and eagles were generally found only in protected areas, with fewer individuals in the surrounding buffer zones and nearly none elsewhere. Conversely, the abundance of most of the smaller species was not different between protected and cultivated areas, and three species were more abundant in cultivated areas. Helmeted guineafowl Numida meleagris, Stanley's bustard Neotis denhami and Abyssinian ground hornbill Bucorvus abyssinicus
\end{abstract}

were not found outside protected areas. Within the 1.4 million ha of protected areas in and around southeast Burkina Faso, six species of eagles and vultures have estimated populations of $c$. 100-200 pairs, five species c. 50-100 pairs, five species have populations of $<50$ pairs, and the secretary bird Sagittarius serpentarius was not recorded. No specific reason for the collapse of large raptors in non-protected areas (which account for $99 \%$ of the area of the countries studied) has been identified, but the consequences of fast human population growth and habitat changes, overhunting, disturbances and poisoning may have played a critical role. Updating information on the conservation status of these species would be an important first step towards their long-term conservation.

Keywords Burkina Faso, distribution, population size, protected areas, raptors, savannah, West Africa.

\section{Introduction}

Diurnal raptors (Falconiforms) are large predators that are widespread and diversified in most habitats but sensitive to pollutants and disturbances and therefore good indicators of ecosystem health and biodiversity. Using large-scale comparative roadside counts in West Africa over $>30$ years I have documented the severe decline of several species (Thiollay, 2001, 2006a,b). Eagles and vultures have almost disappeared from non-protected areas but maintain significant populations in National Parks.

The first objective of the present study was to assess the relative conservation value of protected areas for large raptors in central West Africa compared to the non-protected countryside. The second objective was to estimate the breeding population size of these species, as an indicator of their long-term viability, within the

Jean-Marc Thiollay Museum National d'Histoire Naturelle, CERSP, 55 rue de Buffon, 75005 Paris, France. E-mail jm.thiollay@wanadoo.fr

Received 22 August 2005. Revision requested 8 June 2006 Accepted 24 October 2006.
National Parks across the south-eastern border of Burkina Faso. Although it was not possible to assess other components of population viability, such as breeding and mortality rates, documenting the quantitative and geographical scale of population collapse and fragmentation may give an insight into the future and the vulnerability of raptor populations. These data will help to define a general conservation strategy for raptors in this region, and also indicate the need to review the conservation status of some species that were considered widespread or common until recently but may soon become threatened.

\section{Study area}

The area surveyed was in south-east Burkina Faso from Ouagadougou south to the borders of Ghana and Benin and east to Niger (Fig. 1). The protected areas it encompassed were: (1) the Nazinga game ranch, a 93,000 ha hunting reserve; (2) the 76,000 ha Arli National Park along the Benin border and the contiguous 275,000 ha Pendjari National Park (referred to here as Arli-Pendjari); (3) the 957,000 ha W National Park across the borders of Burkina Faso, Niger and Benin. The surrounding, little 


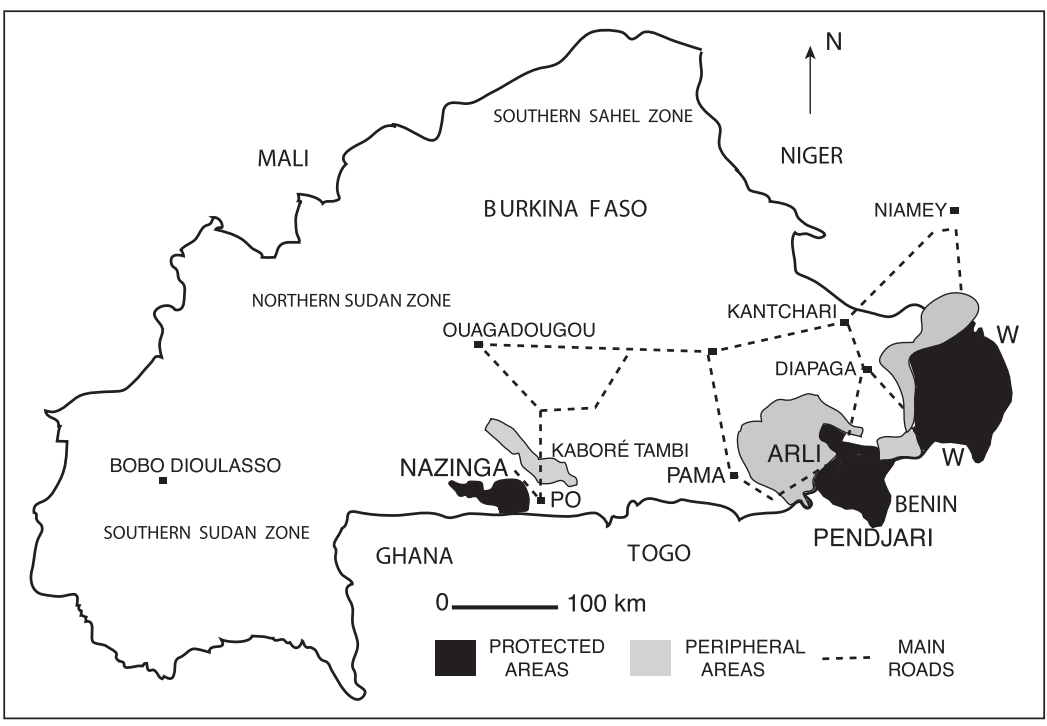

Fig. 1 Study area in Burkina Faso and across its south-eastern border, showing villages and protected areas. The simplified roads shown on the map were used as the main transects outside protected areas. inhabited buffer zones included, respectively: (1) the heavily poached 155,000 ha Kaboré Tambi National Park, north of Nazinga; (2) the 600,000 ha Singou, Arli, Pama and Madjoari hunting areas, north and west of Arli; (3) the $>200,000$ ha hunting areas north (TapoaDjerma) and south-west (Kondio-Kourtiagou) of $\mathrm{W}$ National Park. In Benin only the Pendjari National Park, and not the $>300,000$ ha hunting areas south of this and W National Parks, were surveyed. Latitudinally, the study area ranged between $11^{\circ} \mathrm{N}$ (Pendjari) and $13^{\circ} \mathrm{N}$ (south of Niamey, Niger), i.e. all within the Sudan vegetation zone.

The natural vegetation of these areas is an open 10-20 m high savannah woodland dominated by partly deciduous trees (Burkea, Crossopteryx, Piliostigma, Isoberlinia, Combretum, Pterocarpus, Afzelia). Gallery forests along permanent or seasonal streams include large trees (Khaya, Kigelia, Terminalia, Anogeissus) with a denser understorey (Vitex, Cola, Prosopis). Locally baobabs (Adansonia) are common in grasslands, Borassus palms in floodplains, and Mitragyna in seasonally inundated zones. At the northern edge of the area thorny trees (Acacia, Balanites) become frequent. The grass cover (Hyparrhenia, Andropogon, Loudetiopsis, Pennisetum) usually reaches $1.2-1.8 \mathrm{~m}$ during the rainy season (April-September) and is burnt in the dry season (October-March).

Outside protected or hunting areas the countryside is inhabited and cultivated, with only remnants of degraded woodlands. Traditionally fields of millet, sorghum, maize, groundnut or yam are dotted with large trees (Butyrospermum, Parkia, Tamarindus, Bombax, Acacia). During the dry season the stubble is grazed by cattle. Because of land scarcity, fallow areas are decreasing in size and duration laid to fallow. Intensive cultivation of cotton, with heavy pesticide use, is spreading at the expense of traditional crops.

\section{Methods}

\section{Census techniques}

Transect counts were performed in the mid dry season (late December to mid February) of 2004 and 2005, i.e. when most raptors are breeding. The counts were used to calculate an abundance index and estimate density (Bibby et al., 2000). Transects were road segments crossing a uniform habitat type and long enough $(>30 \mathrm{~km})$ to include a sufficient number of records to offset the stochastic variation of bird sightings. They were driven slowly $\left(<50 \mathrm{~km} \mathrm{~h}^{-1}\right)$ by car, with two non-driving observers, with stops to search for raptors at lookouts and to identify distant birds, in fine weather from after sunrise to before sunset. Most transects were driven twice in the same year, and were used as single counts in which the maximum number of individuals of each species recorded in any one passage was retained. When the same transect was repeated in different seasons it was considered as two separate counts. All birds, perched or flying, detected within eyesight range on either side, even during stops, were counted, using $10 * 42$ binoculars. Age, position (using a geographical positioning system), grouping, behaviour and distance to the track of perched birds (estimated by eye after training sessions) were recorded. In all 3,714 individual raptors were counted over $4,697 \mathrm{~km}$ of transects.

Because the objective was to assess the relative conservation value of protected areas, the transects were divided into three categories: (1) National Parks (Arli, Pendjari, W) or equivalent reserve (Nazinga); (2) buffer 
areas, i.e. peripheral zones around protected areas that are little disturbed, $10-50 \mathrm{~km}$ wide, devoted to sport hunting, with few isolated fields and villages; (3) all other areas, cultivated and inhabited.

During counts our average speed tended to be higher on roads outside than inside protected areas. Moreover, the latter, designed for wildlife viewing, tended to follow gallery forests along rivers and open grasslands and pools, i.e. usually the richest areas for raptors. These factors could have resulted in an overestimate of the abundance of some species in protected areas, or of population size when extrapolated to entire parks. Conversely, the detection of raptors may have been higher in cultivated areas, which are more open than natural woodlands. The behaviour and detectability of raptors change with time of day but the three habitat categories were surveyed throughout the day and there was no overall difference between them in the daily distribution of counts. Nests were searched for carefully and checked when encountered. Some nests with fresh signs of occupancy were empty at the time of visit, and recently fledged young and unsuccessful nests may have been missed.

\section{Data analysis}

To account for unequal transect lengths, species' counts on each transect were expressed as number of individuals per $100 \mathrm{~km}$. This abundance index was used only in comparisons between areas, not between species that had different detectabilities. The significance of differences in abundances between areas was assessed using a Kruskal-Wallis one-way ANOVA $(\mathrm{P}<0.05)$ on the means of all transects involved.

Densities were estimated based on the perpendicular distances of perched birds to the transect using the software Distance v. 3.5 (Buckland et al., 2001). This was done only for the 13 larger species for which there where $>30$ records collected from all protected areas in total. To minimize biases in distance estimates, field records were grouped into $50 \mathrm{~m}$ wide classes of distances up to $200 \mathrm{~m}$ from the centre line of the transect and $100 \mathrm{~m}$ wide thereafter, and individuals at $>500 \mathrm{~m}$ were excluded. For each species an effective strip width (ESW) from the halfnormal model of Distance (i.e. the best fit model most often selected with the Akaike Information Criterion) was estimated using a cosine adjustment. For species with small sample sizes a maximum reliable width estimate derived from the examination of histograms of detection distances was used instead. This estimate, retaining only adult birds, and assuming that two individuals were equivalent to a territorial pair, was used to calculate a density for all transects and then extrapolated to the full size of each protected area.
Density was also estimated using all 89 (1-12 per species) occupied vulture and eagle nests found in protected areas (there were insufficient records elsewhere) and 70 (1-14 per species) additional pairs of adults far from these nests. These were recorded within the maximum ESW $(500 \mathrm{~m})$ on either side of the transects. Locations from different days were excluded when they were $<2 \mathrm{~km}$ from each other This density was extrapolated to the total area of the protected areas.

\section{Results}

\section{Number of species}

Overall, 37 species were recorded in two or more study areas (Table 1). Four additional species were seen only once (palm-nut vulture Gypohierax angolensis, African cuckoo hawk Aviceda cuculoides, short-toed snake eagle Circaetus gallicus and osprey Pandion haliaetus). The secretary bird, formerly frequent in Arli-Pendjari until the early 1970s (Thiollay, 1977; Green \& Sayer, 1979), was not observed. All 37 species were seen in protected areas (26 in all four areas), 33 in the peripheral zones, and only 20 in cultivated areas. Even though transect lengths were unequal the mean species richness per transect was clearly higher in protected than in peripheral areas, and least in cultivated areas.

The raptors observed can be grouped into five categories according to their distribution and abundance index in protected, peripheral and cultivated areas (Table 1; see also Thiollay, 1977, 1978; Borrow \& Demey, 2001). (1) Lappet-faced vulture Torgos tracheliotos, the largest vulture, and Ayres' hawk eagle Hieraaetus ayresii, the rarest and most localized eagle, were observed only in protected areas. (2) Fish eagle Haliaeetus vocifer, whitebacked, Ruppell's and white-headed vultures Gyps africanus, G. rueppellii and Trigonoceps occipitalis, western banded snake eagle Circaetus cinerascens, bateleur Terathopius ecaudatus, Wahlberg's eagle Aquila wahlbergi, African hawk eagle Hieraaetus spilogaster, long-crested, and martial eagles Lophaetus occipitalis and Polemaetus bellicosus were recorded mostly in protected areas, less frequently in peripheral areas, and never in cultivated areas. Four smaller species, uncommon in Burkina Faso where they are near the edge of their breeding distribution, were also recorded only in protected areas and their periphery, although they could extend locally into more cultivated areas: lizard buzzard Kaupifalco monogrammicus, red-necked buzzard Buteo auguralis, African hobby Falco cuvieri and peregrine falcon F. peregrinus. (3) Beaudouin's and brown snake eagles Circaetus beaudouini and C. cinereus, gymnogene Polyboroides typus, and tawny eagle Aquila rapax had their highest abundance index in protected areas, were fewer in peripheral 
Table 1 Total number of individual raptors recorded in transect counts (with mean number per $100 \mathrm{~km}$ of driven transect in parentheses) in the three protected areas surveyed and in the peripheral and cultivated areas (Fig. 1).

\begin{tabular}{|c|c|c|c|c|c|}
\hline \multirow[b]{2}{*}{ Species } & \multicolumn{3}{|c|}{ Protected areas } & \multirow[b]{2}{*}{ Peripheral areas } & \multirow[b]{2}{*}{ Cultivated areas } \\
\hline & Nazinga & Arli/Pendjari & W National Park & & \\
\hline Black-shouldered kite Elanus caeruleus & & $1(0.2)$ & & $4(0.3)$ & $4(0.2)$ \\
\hline Swallow-tailed kite Chelictinia riocourii ${ }^{1 \mathrm{a}}$ & & $3(0.6)$ & $5(0.7)$ & $1(0.1)$ & $4(0.2)$ \\
\hline Black kite Milvus migrans & $10(2.6)$ & $7(1.4)$ & $7(0.9)$ & $87(6.7)$ & $135(7.8)$ \\
\hline Fish eagle Haliaeetus vocifer & $9(2.3)$ & $22(4.4)$ & $19(2.5)$ & $1(0.1)$ & \\
\hline Hooded vulture Necrosyrtes monachus & $66(17.1)$ & $107(21.2)$ & $34(4.4)$ & $527(40.5)$ & $1,254(72.2)$ \\
\hline White-backed vulture Gyps africanus & $51(13.2)$ & $83(16.4)$ & $178(23.2)$ & $30(2.3)$ & \\
\hline Ruppell's griffon vulture Gyps rueppellii & $2(0.5)$ & $33(6.5)$ & $24(3.1)$ & $21(1.6)$ & \\
\hline Lappet-faced vulture Torgos tracheliotus ${ }^{1 a}$ & $2(0.5)$ & $7(1.4)$ & $9(1.2)$ & & \\
\hline White-headed vulture Trigonoceps occipitalis & $6(1.6)$ & $8(1.6)$ & $7(0.9)$ & $2(0.2)$ & \\
\hline Beaudouin's snake eagle Circaetus beaudouini & $1(0.3)$ & 19(3.8) & $6(0.8)$ & $3(0.2)$ & $1(0.1)$ \\
\hline Brown snake eagle Circaetus cinereus & $1(0.3)$ & $7(1.4)$ & $29(3.8)$ & $8(0.6)$ & $4(0.2)$ \\
\hline Western banded snake eagle Circus cinerascens & $2(0.5)$ & $1(0.2)$ & $6(0.8)$ & $1(0.1)$ & \\
\hline Bateleur Terathopius ecaudatus & $68(17.6)$ & $59(11.7)$ & $95(12.4)$ & $17(1.3)$ & \\
\hline Gymnogene Polyboroides typus & $3(0.8)$ & $10(2.0)$ & $5(0.7)$ & & $2(0.1)$ \\
\hline Eurasian marsh harrier Circus aeruginosus ${ }^{2}$ & $7(1.8)$ & $17(3.4)$ & $7(0.9)$ & $13(1.0)$ & $11(0.6)$ \\
\hline Pallid harrier Circus macrourus ${ }^{2}$ & & $3(0.6)$ & $2(0.3)$ & $1(0.1)$ & \\
\hline Montagu's harrier Circus pygargus ${ }^{2}$ & $2(0.5)$ & $17(3.4)$ & $6(0.8)$ & $4(0.3)$ & $3(0.2)$ \\
\hline Dark chanting goshawk Melierax metabates & $7(1.8)$ & $9(1.8)$ & $13(1.7)$ & $22(1.7)$ & $24(1.4)$ \\
\hline Gabar goshawk Micronisus gabar & $4(1.0)$ & $15(3.0)$ & $16(2.1)$ & $10(0.8)$ & $9(0.5)$ \\
\hline Shikra Accipiter badius ${ }^{1 \mathrm{~b}}$ & $12(3.1)$ & $11(2.2)$ & $10(1.3)$ & $10(0.8)$ & $4(0.2)$ \\
\hline Grasshopper buzzard Butastur rufipennis ${ }^{1 \mathrm{~b}}$ & $17(4.4)$ & $2(0.4)$ & $3(0.4)$ & $33(2.5)$ & $3(0.2)$ \\
\hline Lizard buzzard Kaupifalco monogrammicus & $4(1.0)$ & $1(0.2)$ & & $1(0.1)$ & \\
\hline Red-necked buzzard Buteo auguralis ${ }^{1 \mathrm{~b}}$ & & $3(0.6)$ & $1(0.1)$ & $5(0.4)$ & \\
\hline Wahlberg's eagle Aquila wahlbergi $i^{1 \mathrm{~b}}$ & $3(0.8)$ & $11(2.2)$ & $7(0.9)$ & $4(0.3)$ & \\
\hline Tawny eagle Aquila rapax & & $5(1.0)$ & & $2(0.2)$ & $1(0.1)$ \\
\hline African hawk eagle Hieraaetus spilogaster & $3(0.8)$ & 2(0.4) & $20(2.6)$ & $1(0.1)$ & \\
\hline Booted eagle Hieraaetus pennatus ${ }^{2}$ & $3(0.8)$ & $1(0.2)$ & $6(0.8)$ & $8(0.6)$ & $6(0.3)$ \\
\hline Ayres' hawk eagle Hieraaetus ayresii & & $3(0.6)$ & $1(0.1)$ & & \\
\hline Long-crested eagle Lophaetus occipitalis & & $2(0.4)$ & & $1(0.1)$ & \\
\hline Martial eagle Polemaetus bellicosus & $4(1.0)$ & $1(0.2)$ & $7(0.9)$ & $1(0.1)$ & \\
\hline Common kestrel Falco tinnunculus ${ }^{2}$ & $2(0.5)$ & $4(0.8)$ & $1(0.1)$ & $10(0.8)$ & $8(0.5)$ \\
\hline Fox kestrel Falco alopex & & $3(0.6)$ & $1(0.1)$ & $9(0.7)$ & $1(0.1)$ \\
\hline Grey kestrel Falco ardosiaceus & $25(6.5)$ & $6(1.2)$ & $25(3.3)$ & $10(0.8)$ & $3(0.2)$ \\
\hline Red-necked falcon Falco chicquera & $2(0.5)$ & $4(0.8)$ & & & $2(0.1)$ \\
\hline African hobby Falco cuvieri & $2(0.5)$ & & & $1(0.1)$ & \\
\hline Lanner falcon Falco biarmicus & $7(1.8)$ & $1(0.2)$ & $3(0.4)$ & $6(0.5)$ & $9(0.5)$ \\
\hline Perergrine falcon Falco peregrinus & $3(0.8)$ & $3(0.6)$ & $1(0.1)$ & $1(0.1)$ & \\
\hline Number of transects (total length, $\mathrm{km}$ ) & $6(386)$ & $7(505)$ & $10(768)$ & $17(1,300)$ & $18(1,738)$ \\
\hline Total no. of species & 31 & 38 & 32 & 33 & 20 \\
\hline Individuals per $100 \mathrm{~km}^{3}$ & 67.9 & 75.6 & 67.7 & 25.2 & 13.5 \\
\hline
\end{tabular}

${ }^{1}$ Intra-African migrants, i.e. species that were near their southern ${ }^{\mathrm{a}}$ or northern ${ }^{\mathrm{b}}$ dry season latitudinal limit. Many other species may perform more partial seasonal movements (Thiollay, 1978).

${ }^{2}$ Palearctic wintering migrants. The common kestrel has also a resident breeding population.

${ }^{3}$ Excluding the hooded vulture

zones and rarer in cultivated areas (Kruskal-Wallis ANOVAs, $\mathrm{P}<0.001)$. Seven smaller species exhibited a similar trend, significant in four cases $(P<0.01)$, but were still frequent in cultivated areas: swallow-tailed kite Chelictinia rioucourii, pallid and Montagu's harriers Circus macrourus and C. pygargus, Gabar goshawk Micronisus gabar, shikra Accipiter badius, grey kestrel Falco ardosiaceus and red-necked falcon F. chicquera. (4) There was no significant difference in abundance between the three areas for the marsh harrier Circus aeruginosus, chanting goshawk Melierax metabates, grasshopper buzzard Butastur rufipennis, booted eagle Hieraaetus pennatus, common and fox kestrels Falco tinnunculus and F. alopex and lanner falcon F. biarmicus. (5) The blackshouldered kite Elanus caeruleus, black kite Milvus migrans and hooded vulture Necrosyrtes monachus were significantly more abundant in cultivated and peripheral areas than in protected areas (Kruskal-Wallis ANOVAs, $\mathrm{P}<0.001)$. These species are often associated with human settlements and fields. 
In summary, with respect to distribution there were three different categories of species: (1) The hooded vulture, black kite and black-shouldered kite all ( $\mathrm{n}=2,243$ individuals) increased in mean abundance $(\mathrm{P}<0.001)$ from protected $(14.0$ per $100 \mathrm{~km}$ ) to peripheral (47.5 per $100 \mathrm{~km}$ ) and to cultivated areas (80.2 per $100 \mathrm{~km}$ ). (2) Four large vultures and 12 eagles decreased dramatically from protected $(50.2$ per $100 \mathrm{~km})$ to peripheral $(7.7$ per $100 \mathrm{~km})$ and to cultivated areas $(0.6$ per $100 \mathrm{~km}$; $\mathrm{n}=945, \mathrm{P}<0.001)$. (3) All other 18 taxa declined significantly from protected (18.6 per $100 \mathrm{~km})$, to peripheral $(9.8$ per $100 \mathrm{~km})$ and to cultivated areas $(4.8$ per $100 \mathrm{~km}$; $\mathrm{n}=518, \mathrm{P}=0.012$ ). Among them, the proportion of Palearctic wintering migrants (three species of harrier, booted eagle and common kestrel), which naturally associate with open grasslands, was higher in cultivated areas $(28.3 \%)$ than in other habitats $(11 \%$ of all raptors, excluding vultures, $\mathrm{n}=133, \chi^{2}$ tests, $\left.\mathrm{P}<0.001\right)$.

\section{Differences between protected areas}

On the Nazinga game ranch Ruppell's and lappet-faced vultures, the swallow-tailed kite and the pallid harrier were virtually absent because the ranch is close to the southern limit of their dry season range. Conversely, the shikra, lizard and red-necked buzzards were significantly $(\mathrm{P}<0.002)$ rarer in $\mathrm{W}$ National Park at the northern limit of their breeding range. The gymnogene and Wahlberg's eagle were significantly more common $(\mathrm{P}<0.01)$ in Arli and Pendjari National Parks where their favoured gallery forests with Borassus palms are extensive. Marsh and Montagu's harriers and Beaudouin's snake eagle were also most abundant $(P<0.001)$ in these Parks, where their preferred large open grasslands are best represented. Conversely, the brown snake eagle and African hawk eagle, associated with dry, closed savannah woodlands, were most frequent $(P<0.001)$ in W National Park where this habitat is dominant. The current rarity of tawny and long-crested eagles, even in National Parks, is unexplained. They were formerly widespread to the extent that they were the eagles most often encountered in cultivated areas.

\section{Large terrestrial birds}

Large terrestrial birds of the Sudanian savannah belt are among the species most sensitive to hunting, habitat degradation and disturbance, and are also those that have declined most dramatically in West Africa: the Abyssinian ground hornbill Bucorvus abyssinicus needs large trees for breeding, the helmeted guineafowl $\mathrm{Nu}$ mida meleagris lives in flocks in open woodlands, and the solitary Stanley's bustard Neotis denhami lives in wooded grasslands. Twenty-two, 2,816 and 10 individuals, re- spectively, were counted of which not one was seen in cultivated areas (compared to several hundreds along the same roads 30 years ago), and only one hornbill and one guineafowl were counted in peripheral areas, a striking demonstration of the impact of hunting and other habitat or human disturbances in non-protected areas. The guineafowl was much less abundant $(\mathrm{P}<0.001)$ in the hunted Nazinga game ranch (37.6 per $100 \mathrm{~km})$ than in the National Parks (205-217 per 100 km).

\section{Estimated breeding population sizes in protected areas}

The estimated number of pairs from distance sampling of individuals counted and from nests found, extrapolated over the total size of the three protected areas, are given in Table 2, along with corrected estimates for the whole area based on the species distribution and ecology, as described here. Because $>60 \%$ of hooded vultures were encountered around human settlements at park entrances or tourist facilities, their breeding population over all protected areas may have been overestimated by the sampling method. Similarly, breeding white-backed vultures were widespread but semicolonial and patchily distributed. Only 7 pairs of Ruppell's griffon vultures were actually found breeding, in cliffs in Arli and on trees in W; many individuals may be dry season visitors from Sahelian breeding populations, and the number of foraging individuals may exceed 100 . Although adult pairs of lappet-faced vultures were seen several times in $W$ and Pendjari, no occupied nest was seen (although Shull et al., 1986, mentioned it as breeding); most individuals in the Sudan belt may be dry season visitors from the Sahel. The solitary breeding white-headed vulture is mostly a Sudanian and sedentary species; its nests were on top of baobab trees, far apart in natural woodlands, and in Nazinga the three nests found were the only ones known in 1995 (Weesie \& Belemsobgo, 1997). Foraging Beaudouin's snake eagles are conspicuous but their nests are concealed; most were associated with large open grasslands, a habitat disproportionately represented along transect roads, and therefore their population may be overestimated; some were still found outside protected areas, even in fields. Brown snake eagles seldom hunted in flight, but perched at the top of isolated dominant trees, in every habitat, even outside protected areas; individual home ranges may be up to $200 \mathrm{~km}^{2}$ (Ferguson Lees \& Christie, 2001). The small, perch-hunting, secretive western banded snake eagle was strictly associated with gallery forests or dense humid woodlands, patchily distributed in protected areas only; it has the same restricted habitat elsewhere and is one of the rarest raptors of the GuineoSudanian belt. African fish eagles occurred along rivers 
Table 2 Estimated number of pairs from distance sampling of individuals counted (first figure) and from nests found (second figure) for 16 raptor species (see text for details), extrapolated over the total size of the three protected areas (the actual counts are in Table 1), and corrected estimates for the whole area based on knowledge of the species' distribution and ecology (see text for details). Only the medians of the $95 \%$ confidence intervals are given.

\begin{tabular}{lllll}
\hline Species & Nazinga & Arli-Pendjari & W National Park & Corrected estimates \\
\hline Hooded vulture & 12,20 & 71,88 & 104,176 & \pm 100 \\
White-backed vulture & 15,28 & 66,90 & 312,384 & $<300$ \\
Ruppell's griffon vulture & & 33,47 & 41,68 & $10,20 ?$ \\
Lappet-faced vulture & & 11,28 & 18,26 & $2,10 ?$ \\
White-headed vulture & 4,10 & 12,33 & 37,94 & $40,70 ?$ \\
Beaudouin's snake eagle & 2,5 & 47,55 & 70,94 & $<100$ \\
Brown snake eagle & 2,5 & 28,44 & 135,214 & 160,250 \\
Western banded snake eagle & 5,10 & 11,15 & 80,120 & \pm 100 \\
African fish eagle & 6,15 & 18,47 & 56,108 & $<100$ \\
Bateleur & 2,15 & 23,44 & 98,152 & 100,200 \\
Tawny eagle & & & & Too few records \\
Wahlberg's eagle & 6,10 & 20,33 & 52,65 & \pm 100 \\
African hawk eagle & 4,10 & 2,11 & 125,204 & 130,220 \\
Ayres' hawk eagle & & & Too few records \\
Long-crested eagle & & & 37,94 & Too few records \\
Martial eagle & 2,10 & 2,11 & 368 & 40,100 \\
Area surveyed $\left(\mathrm{km}^{2}\right)^{1}$ & 169 & 3.9 &
\end{tabular}

${ }^{1}$ Length of separate transects surveyed one or more times $(\mathrm{km}) * 1 \mathrm{~km}$ width (i.e. $500 \mathrm{~m}$ on each side)

${ }^{2}$ Percentage of the total protected area that was effectively surveyed

and pools, which transect roads followed, and this made the upper extrapolations unrealistic. The Bateleur's abundance is probably overestimated because of the conspicuousness of flying adults; it occurred over all protected areas, was much rarer in buffer zones, and absent elsewhere. The percentage of immature birds (1-5 years pooled) was significantly higher $\left(\chi^{2}\right.$ tests, $\left.\mathrm{P}<0.001\right)$ in Nazinga $(76.6 \%, \mathrm{n}=64)$ than in $\mathrm{W}(37.5 \%, \mathrm{n}=88)$ and Arli-Pendjari $(22.6 \%, n=62)$. Several roosts of 3-9 immature birds were found. Using an average home range of $150 \mathrm{~km}^{2}$ per pair (Ferguson Lees \& Christie, 2001) would give $<100$ pairs. Wahlberg's eagle is an uncommon African migrant, widespread in wet areas with large trees. Pairs of African hawk eagles typically hunt and roost together in savannah woodlands; the estimate of the population in Nazinga is consistent with that of Weesie \& Belemsobgo (1997), and the corrected estimate (Table 2 ) would match the mean territory size of $50-110 \mathrm{~km}^{2}$ per pair given by Ferguson Lees \& Christie (2001). Ayres' hawk eagle was already the rarest eagle in Sudanian and Guinean woodlands 30 years ago (Thiollay, 1977) and, based on the few recent records, a total of 10-20 pairs may remain in the National Parks of all three countries. Long-crested eagles, formerly widespread, may have a similar abundance to Ayres' hawk eagle. The martial eagle, the largest of the region's eagles, may have also the largest average home range (150-300 km² per pair; Ferguson Lees \& Christie, 2001), and was evenly distributed although apparently more common in W National Park than elsewhere.

\section{Discussion}

Almost nothing is known about the demography of any large raptor species in West Africa. Assessing their viability therefore relies solely on their distributions and population sizes but because only $6.2 \%$ of all protected and peripheral areas were surveyed the population estimates are only tentative. However, the small, more thoroughly surveyed Nazinga ranch provided a useful reference against which to check the reliability of the population estimates, and the lower estimates of this study were consistent with the comprehensive work of Weesie \& Belemsobgo (1997).

There was little gradient of natural vegetation from the northern to the southernmost study areas that could account for the difference in the abundance of large raptors between protected areas (mostly in the south) and cultivated areas (more northerly). The breeding range of most eagles and vultures extended well north and south of the study areas and few species are near their southern (lappet-faced vulture, secretary bird) or northern (banded snake eagle, Ayres' hawk eagle) limit. A similar diversity and species composition was found in the National Parks of southern Chad, northern Ivory Coast and eastern Senegal (Thiollay, 1970, 1975a,b). 
Most savannah raptor species were formerly widespread, and even common, in both West, East and South Africa. However, during the last 2 decades serious declines of eagles and vultures have been documented in South Africa (Mundy et al., 1992; Ferguson Lees \& Christie, 2001). Large scale comparative transect counts between 1968-1973 and 2000-2004 have also shown massive declines in West Africa outside the few protected areas (Thiollay, 2001, 2006a,b,c). Large vultures, eagles and terrestrial birds have now largely, if not entirely, disappeared from cultivated and inhabited areas. Their frequency has also decreased in the hunted, but otherwise little disturbed buffer zones, and possibly to a lesser extent in some National Parks (Green \& Sayer, 1979; Koster \& Grettenberger, 1983). On the Nazinga ranch, in the same breeding area where no more than five active nests and eight adults of white-backed vultures were found in 2005, 28 nests and 65 birds were counted in 1992 (Weesie \& Belemsobgo, 1997). Conversely, most smaller raptors remain widespread in the non-protected countryside where some of them are significantly less abundant than in protected areas but others have a similar average abundance, and a few species have even benefited from habitat changes. Similar trends were documented by Herremans \& HerremansTomoeyr (2000) in Botswana.

The National Parks studied here are the main, if not the only effective protected areas in Burkina Faso, Benin and Niger. They cover a total of $14,000 \mathrm{~km}^{2}$, i.e. a mere $0.8 \%$ of the three countries. The additional $12,500 \mathrm{~km}^{2}$ of peripheral game reserves are hunted by shooting parties. In Central West Africa large raptor species are now confined to these protected areas and surrounding natural habitats, i.e. to $1-2 \%$ of their original distribution. Within protected areas species can be divided into three categories: (1) Six species still have sizeable, presumed viable populations, conservatively estimated at 100-200 pairs, widely distributed and occurring in small numbers also in peripheral zones: hooded and white-backed vultures, brown snake eagle, bateleur, Wahlberg's eagle and African hawk eagle. (2) Five species have lower but still widespread populations (c. 50-100 pairs): Beaudouin's and banded snake eagles, fish and martial eagles, and white-headed vulture. (3) Five species are now much rarer and local, probably $<50$ pairs: Ruppell's and lappet-faced vultures, tawny and long-crested eagles, and Ayres' hawk eagle. Such small and scattered populations may be natural (e.g. hawk eagle) but the tawny and long-crested eagles were frequent everywhere 30 years ago and the vultures have declined throughout their mainly Sahelian range (Thiollay, 2006b). Lastly, the formerly widespread Sahelian population of the secretary bird has collapsed and may be facing extinction. It is now the most threatened raptor in West Africa (Thiollay, 2006b). Because of the relative proximity of the different Parks, the known flight range of larger species and the seasonal movements of at least some of them it is likely that the populations studied still function as metapopulations, with regular exchanges of individuals between protected areas, a critical requirement for viable populations

No particular cause of raptor decline has been identified in West Africa beyond anecdotal events. Since the late 1960s I have witnessed the dramatic growth of the human population, the ever increasing degradation or loss of natural habitats, and the spectacular collapse of the populations of large terrestrial birds and mammals, even within protected areas. Probably specific and local factors (e.g. increasing use of pesticides, direct persecution, pollution, overfishing, poisoning of carcasses, and electrocution on powerlines) have played a role in the declines. However, generally decreasing food resources and increasing habitat disturbance may lower the resistance of populations to more temporary or local threats.

As the main, if not last refuge of several eagles and vultures, the protected areas studied are critical for the long-term conservation of raptor diversity. The current size, number and clustered distribution of these areas may guarantee the viability and maintenance of most breeding populations. Each protected area includes a different proportion of habitat types and the latitudinal range of the protected areas extends across the southern or northern distribution limit of several species. Therefore they are likely to be complementary to one another, and together they may harbour viable populations of more species than a single area, provided movements can continue to occur between them. The large, minimally disturbed areas around the National Parks are also probably significant for long-term conservation as buffer zones and additional foraging areas, even though the density of breeding raptors there is generally lower than within the protected areas. Many species, however, may have increasingly fragmented populations, which may be why some of them are declining even inside protected areas.

Monitoring populations and investigating specific causes for decline are obvious recommendations from this work. A first objective, however, should be to update information on the current distribution and abundance of eagles and vultures, and also the secretary bird and bustards, and then to reconsider their conservation status. Currently only one of the 17 large raptors studied (the lappet-faced vulture) is categorized on the IUCN Red List, as Vulnerable (BirdLife International, 2004; IUCN, 2006). Some restricted habitats, such as gallery forests and open grasslands in floodplains, appear to be critical for several raptor species, at least as optimal breeding and foraging sites, and these habitats are 
especially threatened or highly disturbed outside protected areas. An emphasis on their conservation could be a significant step towards improvement of raptor habitats. More generally, the preservation of a variety of little disturbed natural habitats over large areas is a prerequisite to maintain this rich raptor community.

\section{Acknowledgements}

I would like to thank F. Baillon, J.L. Bourrioux, D. Chevallier, J. Coatmeur, Ph. Pilard, F. Thiollay and B. Van Ecke for their invaluable help in the field, which was supported by the UR 136 Aires Protégées of the Institut de Recherche pour le Développement. G. Balança, M.N. de Visscher and J. Roseel of the ECOPAS Project, and S. Sahailou, Director of W National Park, provided logistical help. L.D.C. Fishpool and an anonymous referee made useful comments on a first draft.

\section{References}

Bibby, C.J., Burgess, N.D., Hill, D.A \& Mustoe, S.H. (2000) Bird Census Techniques. Academic Press, London, UK.

BirdLife International (2004) Threatened Birds of the World 2004. CD-ROM, BirdLife International, Cambridge, UK.

Borrow, N. \& Demey, R. (2001) Birds of Western Africa. Christopher Helm, London, UK.

Buckland, S.T., Anderson, D.R., Burnham, K.P., Laake, J.L., Borchers, D.L. \& Thomas, L. (2001) Introduction to Distance Sampling: Estimating Abundance of Biological Populations. Oxford University Press, Oxford, UK.

Ferguson-Lees, J. \& Christie, D.A. (2001) Raptors of the World. Christopher Helm, London, UK.

Green, A.A. \& Sayer, J.A. (1979) The birds of Pendjari and Arli National Parks (Benin and Upper Volta). Malimbus, 1, 14-18.

Herremans, M. \& Herremans-Tomoeyr, D. (2000) Land use and the conservation status of raptors in Botswana. Biological Conservation, 94, 31-41.

IUCN (2006) 2006 IUCN Red List of Threatened Species. IUCN, Gland, Switzerland [http://www.redlist.org, accessed 29 January 2007]

Koster, S.H. \& Grettenberger, J.F. (1983) A preliminary survey of birds in Park W Niger. Malimbus, 5, 62-72.
Mundy, P.J., Botchart, D., Ledger, J. \& Piper, S. (1992) The Vultures of Africa. Academic Press, London, UK.

Shull, B., Grettenberger, J.F. \& Newby, J. (1986) Recent observations of birds in W National Park (Niger). Malimbus, 8, 23-24.

Thiollay, J.M. (1970) Les rapaces du Parc National du Niokolo Koba. Données préliminaires. Oiseau et RFO, 40, 115-130.

Thiollay, J.M. (1975a) Les rapaces des parcs nationaux du Tchad méridional. Oiseau et RFO, 45, 27-40.

Thiollay, J.M. (1975b) Les rapaces des parcs nationaux de Côte d'Ivoire. Analyse du peuplement. Oiseau et RFO, 45, 241-257.

Thiollay, J.M. (1977) Distribution saisonnière des rapaces diurnes en Afrique Occidentale. Oiseau et RFO, 47, 253-294.

Thiollay, J.M. (1978) Les migrations des rapaces en Afrique Occidentale: adaptations écologiques aux fluctuations saisonnières de production des écosystèmes. Terre et Vie, 32, 89-133.

Thiollay, J.M. (2001) Long-term changes of raptor populations in Northern Cameroon. Journal of Raptor Research, 35, 173-186.

Thiollay, J.M. (2006a) Large bird declines with increasing human pressure in savanna woodlands (Burkina Faso). Biodiversity and Conservation, 15, 2805-2108.

Thiollay, J.M. (2006b) The decline of raptors in West Africa: long-term assessment and the role of protected areas. Ibis, 148, 240-254.

Thiollay, J.M. (2006c) Severe declines of large birds in the northern Sahel of West Africa: a long term assessment. Bird Conservation International, 16, 353-365.

Weesie, P.D.M. \& Belemsobgo, U. (1997) Les rapaces diurnes du ranch de gibier de Nazinga (Burkina Faso): liste commentée, analyse du peuplement et cadre biogéographique. Alauda, 65, 263-278.

\section{Biographical sketch}

Jean-Marc Thiollay, research director at the French National Centre of Scientific Research, has spent 40 years studying the ecology and conservation of raptor communities in the tropics. His research focuses on the effects of habitat degradation, fragmentation and hunting pressure, as well as on the design and management of protected areas. He is involved in numerous ecological studies and conservation projects in France, South America and West Africa. 